\title{
Activation-induced upregulation of MMP9 in mast cells is a positive feedback mediator for mast cell activation
}

\author{
$\mathrm{LIN} \mathrm{XU}^{1}$, ZHIJIAN CAI ${ }^{2}$, FEI YANG ${ }^{2}$ and $\mathrm{MING} \mathrm{CHEN}^{1}$ \\ ${ }^{1}$ Department of Otolaryngology, The Second Affiliated Hospital, College of Medicine, Zhejiang University, Hangzhou, \\ Zhejiang 310009; ${ }^{2}$ Institute of Immunology, Zhejiang University School of Medicine, Hangzhou, Zhejiang 310058, P.R. China
}

Received November 9, 2015; Accepted November 15, 2016

DOI: $10.3892 / \mathrm{mmr} .2017 .6215$

\begin{abstract}
Activated mast cells are involved in the pathogenesis of allergic rhinitis (AR). As a member of the matrix metalloproteinase (MMP) family, MMP9 has been previously demonstrated act in a pro-inflammatory manner. Mast cells regulate the activity of MMP9, and mast cells themselves have been reported to produce MMP9. However, to the best of our knowledge, the involvement of MMP9 in mast cell activation remains to be elucidated. The present study demonstrated an upregulation of MMP9 protein and mRNA expression levels in mast cells activated by phorbol ester and ionomycin. Phosphorylated ERK and AKT protein levels also markedly increased in activated mast cells, and inhibition of the ERK and AKT signaling pathways prevented the increase of MMP9 in activated mast cells. MMP9 was demonstrated to be involved in mast cell activation, since inhibition of MMP9 activity or expression inhibited mast cell activation. Furthermore, IL-4 treatment reduced MMP9 upregulation in activated mast cells, and interference with IL-4 signaling with an IL-4 neutralizing antibody promoted MMP9 upregulation in activated mast cells. These results revealed a novel MMP9-mediated mechanism underlying mast cell activation, thus providing novel ideas for AR therapy.
\end{abstract}

\section{Introduction}

Allergic rhinitis (AR) is an immunoglobulin (Ig) E-mediated, non-infectious inflammation of the nasal mucosa, characterized by paroxysmal sneezing, rhinorrhea, nasal itching and nasal obstruction when the susceptible individuals are exposed to allergens (1). The incidence of AR has risen significantly and, in 2010, the disease affected an estimated $10-20 \%$ of the global population (2). AR directly exacerbates other inflammatory airway diseases, including asthma, which threatens the

Correspondence to: Dr Ming Chen, Department of Otolaryngology, The Second Affiliated Hospital, College of Medicine, Zhejiang University, 88 Jiefang Road, Hangzhou, Zhejiang 310009, P.R. China E-mail: zjuchenm@sina.com

Key words: allergic rhinitis, mast cells, MMP9, IL-4, mechanism lives of patients (3). The most effective drugs for the treatment of AR are antihistamines and topical glucocorticoids (1), but while these drugs temporarily alleviate AR symptoms they cannot cure AR altogether. Thus, it is important to further understand the mechanisms underlying AR development, as this will assist the exploration of novel AR therapies.

Mast cells are directly and pathologically involved in AR (4). While AR pathology is dominated by Th2 cells, it remains dependent on the ability of antigen-specific $\operatorname{IgE}$ to bind to FceRI, which is expressed on mast cells. Cross-linkage of FceRI results in the activation of the mast cell and initiation of a signal transduction cascade, leading to the release of tumor necrosis factor- $\alpha$, interleukin (IL)- 4 , histamine, heparin, serotonin, kinins and proteases, which in turn lead to inflammatory cell activation and recruitment, and allergic disease-associated smooth muscle contraction (5). Furthermore, mast cells respond to multiple inflammatory factors, including IgG, cytokines, chemokines, adenosine and sphingosine-1-1phosphate (6-10). The direct relationship between the activation of mast cells and AR pathological responses is well documented, but it is necessary to further elucidate the process of mast cell activation.

The matrix metalloproteinase (MMP) family consists of zinc-dependent endopeptidases (11). MMPs are primarily involved in the cleavage of the extracellular matrix (ECM), but are also involved in a range of biological and pathological processes, including fibrosis, inflammation and wound healing (12). MMP9, a member of the MMP family, has been categorized as a pro-inflammatory factor. Mast cells synthesize ECM components and their adhesive interactions with fibroblasts result in MMP9 release. MMP9 release has been demonstrated to further increase in the presence of $\operatorname{IgE}(13)$. In turn, MMP9 induces the release of cytokines and chemokines from EMC, facilitating the infiltration of immune cells into the inflammation site (14). MMP9 is also closely associated with mast cells. Interactions between mast cells and fibroblast induce MMP9 release from fibroblasts (15) and myocardial mast cells are involved in the regulation of MMP9 activity (16). Mast cell chymase is involved in the activation of pro-MMP9 and MMP2 (17), and tryptase-producing mast cells may be associated with MMP2 and MMP9 expression (18). Notably, human mast cells produce MMP9 themselves (19). However, to the best of our knowledge, the regulation of MMP9 production in mast cells and its effects on mast cell activation remains unknown. 
In the present study, MMP9 expression was demonstrated to increase in activated mast cells in an AKT and ERK signaling pathway-dependent manner, and increased MMP9 levels were implicated in the activation of mast cells. Furthermore, the increased expression of MMP9 in activated mast cells was inhibited by IL-4.

\section{Materials and methods}

Reagents. Phorbol ester (PMA) and ionomycin (ION) were purchased from Sigma-Aldrich, Merck Millipore (Darmstadt, Germany). Murine IL-4 and IL-6 ELISA kits were purchased from eBioscience, Inc. (San Diego, CA, USA). TRIzol reagent was purchased from Invitrogen; Thermo Fisher Scientific, Inc. (Waltham, MA, USA). Antibodies against ERK2/1 (MK1; cat. no. sc-135900; 1:400), AKT (C-20; cat. no. sc-1618; 1:200), phosphorylated (p)-ERK (E-4) (cat. no. sc-7383; 1:400), p-AKT-Thr308 (cat. no. sc-16646; 1:200) and MMP9 (cat. no. sc-6841; 1:400), the ERK/MAPK inhibitor U0126, the AKT inhibitor MK2206 and the MMP9 inhibitor CTK8G1150, and MMP9 small interfering RNA (siRNA) (cat. no. sc-29401; 1:400) were all purchased from Santa Cruz Biotechnology, Inc. (Dallas, TX, USA). For transient silencing of MMP9, 21-nt sequences of siRNA duplexes were synthesized (GenePharma, Shanghai, China): sense 5'-CAUUCAG GGAGACGCCCAUUUTT-3' and antisense 5'-AAAUGG GCGUCUCCCUGAAUGTT-3'; scramble control siRNA sense 5'-UUCUCCGAACGUGUCACGUTT-3' and antisense 5'-ACGUGACACGUUCGGAGAATT-3'. A total of $40 \mathrm{nM}$ siRNA duplexes was transfected reagent on a 24-well plate. The efficiency of MMP9 transient silencing was confirmed by western blotting. Recombinant murine IL-4 (cat. no. 404-ML; 1:200) and murine IL-4 antibodies (cat. no. MAB404; 1:200); were purchased from R\&D Systems, Inc. (Minneapolis, MN, USA).

Cells and cell culture. The murine mast cell P815 cell line and human mast cell HMC-1 cell line were obtained from the American Type Culture Collection (Manassas, VA, USA). RPMI-1640 supplemented with L-glutamine, sodium pyruvate, non-essential amino acids, a 2-fold vitamin solution, and penicillin-streptomycin (Invitrogen; Thermo Fisher Scientific, Inc.). Fetal bovine serum (FBS; HyClone; GE Healthcare Life Sciences, Logan, UT, USA) or horse serum (Invitrogen; Thermo Fisher Scientific, Inc.) was added to the media. All cultures were performed at $37^{\circ} \mathrm{C}$ in a $5 \% \mathrm{CO}_{2}$ atmosphere.

Cytokine assay and $\beta$-hexosaminidase release. A total of $2 \times 10^{5}$ P815 or HMC-1 cells were stimulated with 50 nM PMA and $500 \mathrm{nM}$ ION for $24 \mathrm{~h}$, and were subsequently centrifuged at $400 \mathrm{x} \mathrm{g}$ for $5 \mathrm{~min}$ at $25^{\circ} \mathrm{C}$. Cell supernatant was collected and IL- 4 and IL- 6 levels were measured by ELISA, according to the manufacturer's protocol. To detect degranulation, $50 \mu \mathrm{l}$ supernatant was removed for $\beta$-hexosaminidase measurement, and deionized water was added to the remaining cell pellets. The samples were frozen, thawed, and a second $50 \mu \mathrm{l}$ was removed to determine the total $\beta$-hexosaminidase content. $\beta$-hexosaminidase samples $(50 \mu \mathrm{l})$ were incubated in $0.04 \mathrm{M}$ citric acid with $0.02 \mathrm{M} \mathrm{Na}_{2} \mathrm{HPO}_{4}$ containing $10 \mathrm{mM}$ p-nitrophenyl $\mathrm{N}$-acetyl- $\alpha$-D-glucosaminide for $90 \mathrm{~min}$ at $37^{\circ} \mathrm{C}$. The reaction was developed using $0.4 \mathrm{M}$ glycine and the absorbance was determined at $405 \mathrm{~nm}$. The release percentage was calculated as follows: $[\beta$-hexosaminidase in supernatant $/(\beta$-hexosaminidase in supernatant + total $\beta$-hexosaminidase in pellet)] $\times 100$.

Reverse transcription-quantitative polymerase chain reaction $(R T-q P C R)$. The total RNA was extracted using TRIzol reagent. and cDNA was synthesized using a PrimeScript ${ }^{\mathrm{TM}}$ RT reagent kit (Takara Bio, Inc., Otsu, Japan), according to the manufacturer's protocol. The following primers were used: $\beta$-actin, forward: 5'-CGTTGACATCCGTAAAGACC-3' and reverse: 5'-AACAGTCCGCCTAGAAGCAC-3'; MMP9, forward: 5'-CGGCACGCCTTGGTGTAGCA-3' and reverse: 5'-GGCGCACCAGCGGTAACCAT-3'. The following PCR conditions were used: 1 cycle of $95^{\circ} \mathrm{C}$ for $30 \mathrm{sec}$ followed by 40 cycles of $95^{\circ} \mathrm{C}$ for $5 \mathrm{sec}$ and $60^{\circ} \mathrm{C}$ for $34 \mathrm{sec}$. RT-qPCR and the $2^{-\Delta \Delta \mathrm{Cq}}$ method was performed on an Applied Biosystems 7500 real time PCR system (Thermo Fisher Scientific, Inc.) with version 2.0.6 software (20).

Inhibition of ERK, AKT and MMP9 activity. To inhibit the ERK and AKT signaling pathways, the $2 \times 10^{5}$ P815 cells were pre-treated for $2 \mathrm{~h}$ with either $100 \mathrm{nM}$ U0126 or $10 \mathrm{nM}$ MK2206, or both, and were then activated using $50 \mathrm{nM}$ PMA and $500 \mathrm{nM}$ ION for $24 \mathrm{~h}$. To inhibit MMP9, the $2 \times 10^{5} \mathrm{P} 815$ cells were pre-treated with $10 \mathrm{nM} \mathrm{CTK8G1150}$ for $2 \mathrm{~h}$ and subsequently activated by $50 \mathrm{nM}$ PMA and $500 \mathrm{nM}$ ION for $24 \mathrm{~h}$. The control group was treated with DMSO.

Western blot analysis. The total proteins were extracted from cells (HMC-1 and P815) using protein extracting buffer [20 mmol/1 Tris- $\mathrm{Cl}$ buffer, $\mathrm{pH} 7.5$, containing $1 \mathrm{mmol} / 1$ ethylenediamine tetraacetic acid, a protease inhibitor cocktail (complete, Mini, ethylenediamine tetraacetic acid-free, 1 tablet of 10-ml buffer; Sigma-Aldrich, Merck Millipore), $1 \%$ sodium dodecyl sulfate, $10 \%$ Triton X-100, and $2 \mathrm{~mol} / \mathrm{l}$ dithiothreitol]. After $30 \mathrm{~min}$ on ice, the samples were centrifuged at $17,600 \times \mathrm{g}$ for $10 \mathrm{~min}$ at $4^{\circ} \mathrm{C}$ ). A total of $20 \mu \mathrm{g}$ crude proteins extracted from cell lysates from HMC-1 and P815 cells were separated on $10 \%$ sodium dodecyl sulfate-polyacrylamide gel electrophoresis (SDS-PAGE) and were subsequently transferred onto polyvinylidene difluoride membranes (Merck Millipore). The membranes were blocked with 5\% FBS in Tris-buffered saline, $\mathrm{pH} 8.0$, plus $0.05 \%$ Tween-20, for $1 \mathrm{~h}$ at room temperature, and were then incubated with the corresponding primary antibodies at $4^{\circ} \mathrm{C}$ overnight. Following washing with Tris-buffered saline plus $0.05 \%$ Tween-20, the membranes were incubated with secondary antibody conjugated to horseradish peroxidase (cat. nos. P-0217, P-0161, P-0160; 1:1,000; Dako; Agilent Technologies, Inc., Santa Clara, CA, USA) was incubated for $1 \mathrm{~h}$ at room temperature. Proteins were visualized using SuperSignal West Femto Maximum Sensitivity Chemiluminescence substrate (Thermo Fisher Scientific, Inc.).

Gelatin zymography. A gelatin zymography assay was performed to investigate the secretion of active MMP9. A total of $4 \times 10^{4}$ of HMC-1 and P815 cells were grown to $70 \%$ confluence, 


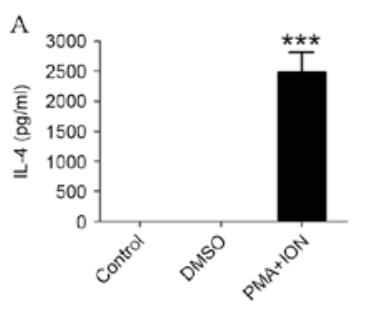

B

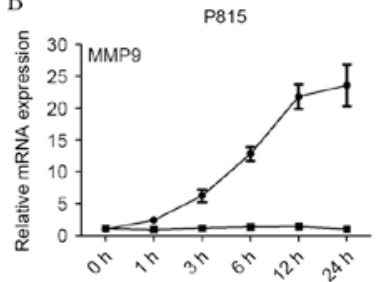

$\mathrm{C}$

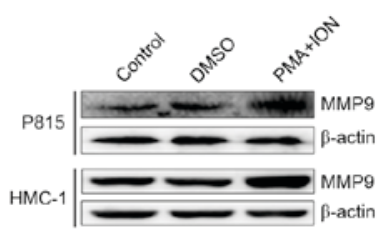

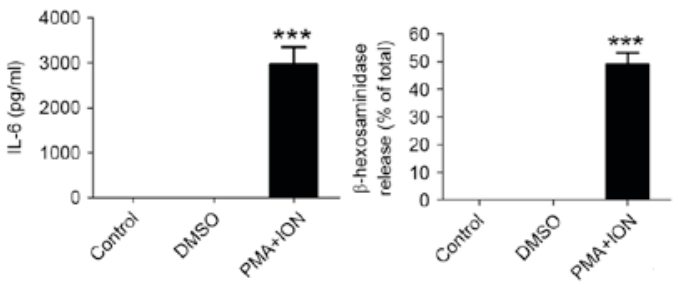

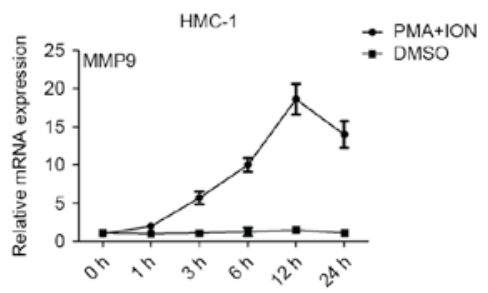

D

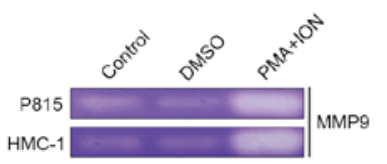

Figure 1. MMP9 expression is upregulated in activated mast cells. (A) IL-4 and IL-6 levels, as determined by ELISA, and degranulation, as determined by $\beta$-hexosaminidase release, in PMA+ION-treated activated P815 cells. (B) The mRNA expression levels of MMP9 in P815 and HMC-1 cells, as detected by reverse transcription-quantitative polymerase chain reaction. (C) The protein expression levels of MMP9 in P815 and HMC-1 cells, as detected by western blotting. (D) The secretion level of MMP9 in activated P815 and HMC-1 cells, as detected by gelatin zymography. The data are represented as the results of three independent experiments ${ }^{* * *} \mathrm{P}<0.001$ vs. DMSO. MMP9, matrix metalloproteinase 9; IL, interleukin; PMA, phorbol ester; ION, ionomycin; DMSO, dimethyl sulfoxide.

washed twice with PBS and incubated in serum-free medium. Conditioned medium was collected $24 \mathrm{~h}$ following this and was concentrated with a centrifugal filter (Merck Millipore) at $6,000 \mathrm{x} \mathrm{g}$ for $15 \mathrm{~min}$ at $4^{\circ} \mathrm{C}$ Concentrated samples were prepared in non-reducing sample buffer (Invitrogen; Thermo Fisher Scientific, Inc.). Proteins (20 $\mu \mathrm{l} / \mathrm{lane})$ were separated by SDS-PAGE on gels containing $1 \mathrm{mg} / \mathrm{ml}$ gelatin (Novex $10 \%$ gelatin gel; Invitrogen; Thermo Fisher Scientific, Inc.). The gels were renatured for $1 \mathrm{~h}$ at room temperature in $1 \mathrm{X}$ renaturing buffer (Invitrogen; Thermo Fisher Scientific, Inc.). Following this, gels were incubated overnight at $37^{\circ} \mathrm{C}$ in $1 \mathrm{X}$ developing buffer (Invitrogen; Thermo Fisher Scientific; Inc.). Gels were stained with Coomassie blue for $2 \mathrm{~h}$ at room temperature. The brightness of the clear bands, where MMP9 was located and the gelatin was degraded, was analyzed according the optical density using Bio-Rad Image Lab version 4.0 (Bio-Rad Laboratories, Inc., Hercules, CA, USA).

RNA interference assay. MMP9 and negative control siRNA duplexes (40 nM) were transfected into cells of HMC-1 and P815 (5x10 $/$ well) using $3 \mu$ INTERFER in siRNA transfection reagent (Santa Cruz Biotechnology, Inc.) in a 24-well plate. The efficiency of MMP9 silencing was confirmed by western blot analysis.

Statistical analysis. Data are presented as the mean \pm standard error. The results were compared using one-way analysis of variance in SPSS version 16 (SPSS, Inc., Chicago, IL, USA). $\mathrm{P}<0.05$ was considered to indicate a statistically significant difference.

\section{Results}

MMP9 expression is upregulated in activated mast cells. Following stimulation with $50 \mathrm{nM}$ PMA and $500 \mathrm{nM}$ ION, P815 cells released significantly increased levels of IL-4, IL-6 and $\beta$-hexosaminidase compared with control cells or DMSO-treated cells $(\mathrm{P}=0.0018, \mathrm{P}=0.0014$ and $\mathrm{P}=0.0002$, respectively; Fig. 1A). HMC-1 cells also had higher levels of IL-4, IL-6 and $\beta$-hexosaminidase (data not shown). Following activation, increased mRNA (Fig. 1B) and protein (Fig. 1C) expression levels of MMP9 were detected in both P815 and HMC-1 cells. To confirm an increase of MMP9 release, MMP9 activity was detected by gelatin zymography. Activated P815 and HMC-1 cells degraded visibly more gelatin compared with the control or DMSO-treated cells (Fig. 1D). These results indicated that MMP9 expression is upregulated in activated P815 and HMC-1 mast cells.

Upregulation of MMP9 in activated mast cells is dependent on the ERK and AKT signaling pathways. The ERK and AKT signaling pathways are involved in the activation of mast cells (21) and have also been reported to induce the expression of MMP9 (22). The present study aimed to establish whether the ERK and AKT signaling pathways are involved in MMP9 upregulation in activated mast cells. Phosphorylated ERK and AKT expression levels were visibly increased in activated P815 cells (Fig. 2A). Following treatment with the ERK-specific inhibitor U0126 or the AKT-specific inhibitor MK2206, PMA+ION treatment-induced increases in MMP9 protein levels were partially inhibited in activated P815 cells 

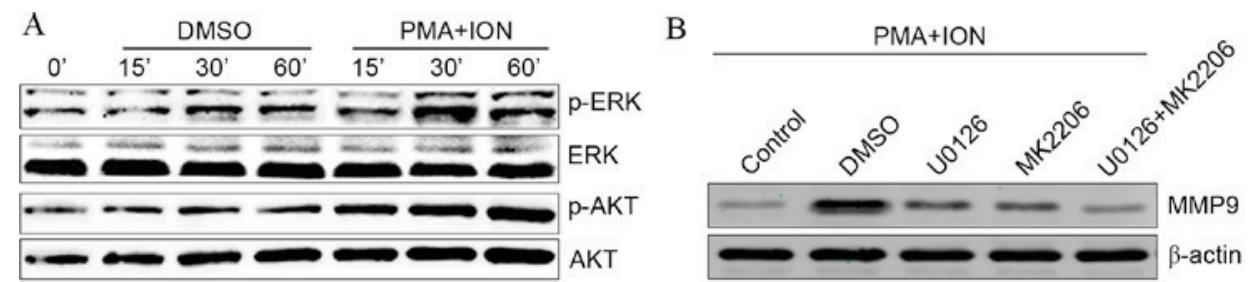

Figure 2. Upregulation of MMP9 in activated mast cells is dependent on the ERK and AKT signaling pathways. (A) The protein expression levels of p-ERK and p-AKT were assessed in activated P815 cells by western blotting. (B) The protein expression levels of MMP9 were determined in activated P815 cells following treatment with ERK and AKT specific inhibitors, U0126 and MK2206, respectively. The data are representative of three independent experiments. MMP9, matrix metalloproteinase 9; ERK, mitogen activated protein kinase; AKT, AKT serine/threonine kinase; p-, phosphorylated; DMSO, dimethyl sulfoxide; PMA, phorbol ester; ION, ionomycin.
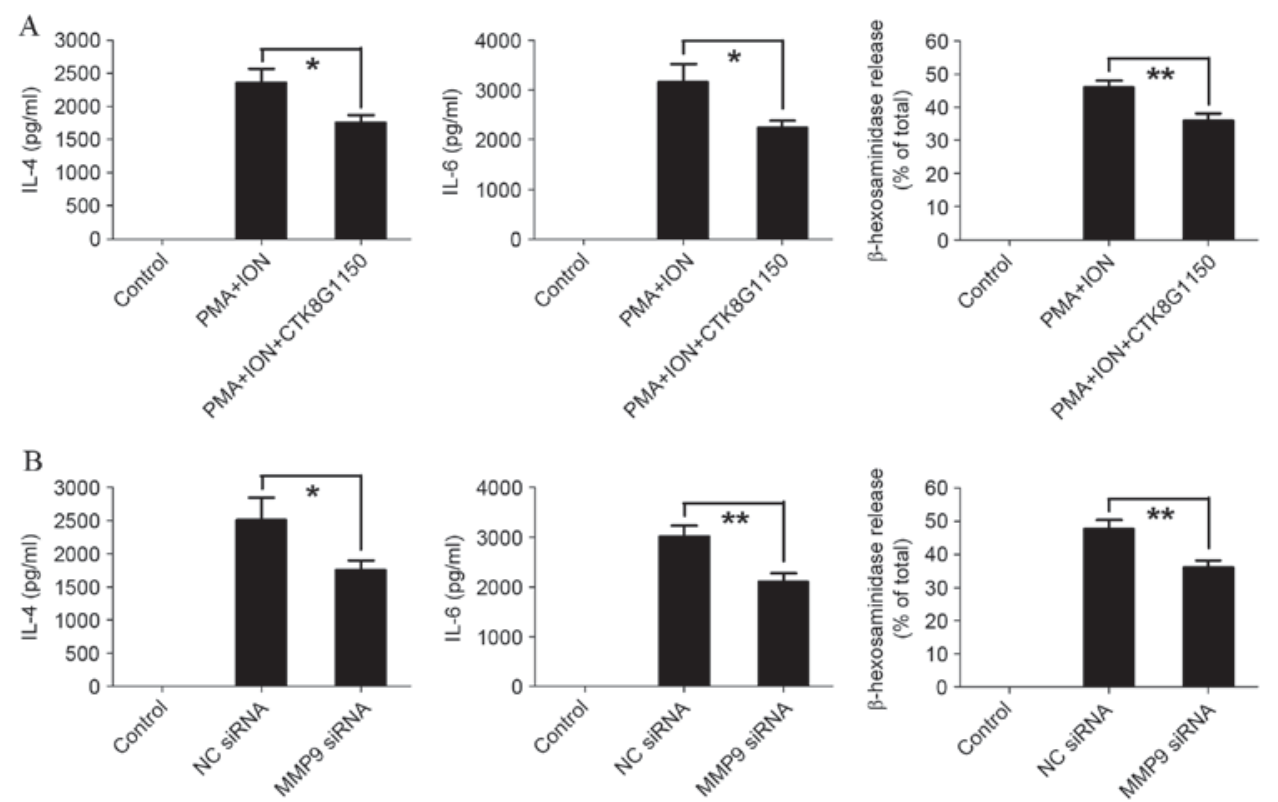

Figure 3. MMP9 promotes the activation of mast cells. (A) The levels of IL-4 and IL-6 were determined by ELISA, and degranulation was determined by $\beta$-hexosaminidase release in activated P815 cells following treatment with the MMP9 specific inhibitor, CTK8G1150 (10 nM). (B) The levels of IL-4 and IL- 6 were determined by ELISA, and degranulation as determined by $\beta$-hexosaminidase release in activated P815 cells following transfection with MMP9 specific siRNA. The data are representative of three independent experiments, and comparisons are indicated by lines. ${ }^{*} \mathrm{P}<0.05,{ }^{* * *} \mathrm{P}<0.01$. MMP9, matrix metalloproteinase 9; IL, interleukin; siRNA, small interfering RNA; PMA, phorbol ester; ION, ionomycin; NC, negative control.
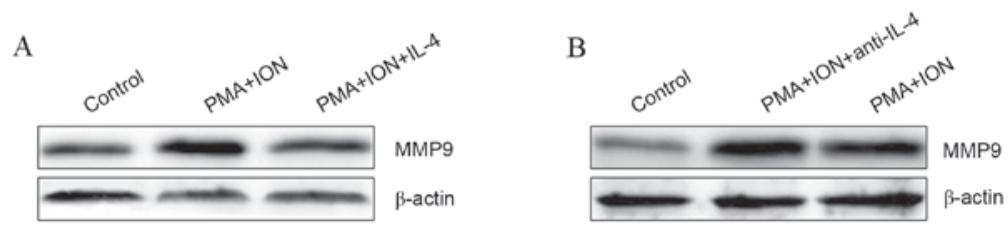

Figure 4. IL-4 inhibits the upregulation of MMP9 in activated mast cells. The protein expression of MMP9 was assessed in activated P815 cells, as detected by western blotting, in response to (A) treatment with $10 \mathrm{ng} / \mathrm{ml} \mathrm{IL}-4$ or (B) $10 \mu \mathrm{g} / \mathrm{ml} \mathrm{IL-4} \mathrm{neutralizing} \mathrm{antibody.} \mathrm{The} \mathrm{data} \mathrm{are} \mathrm{representative} \mathrm{of} \mathrm{three} \mathrm{independent}$ experiments. IL, interleukin; MMP9, matrix metalloproteinase 9; PMA, phorbol ester; ION, ionomycin.

compared with DMSO-treated activated P815 cells (Fig. 2B). Combined treatment with both U0126 and MK2206 appeared to completely abolish increased MMP9 protein levels in activated P815 cells compared with DMSO-treated activated P815 cells (Fig. 2B). These results suggested that the increased MMP9 levels observed in activated mast cells are dependent on the ERK and AKT signaling pathways.

MMP9 promotes the activation of mast cells. To establish the effect of MMP9 on mast cell activation, the MMP9 inhibitor
CTK8G1150 was used. PMA and ION treatment-induced IL-4, IL- 6 and $\beta$-hexosaminidase release significantly decreased in CTK8G1150-treated P815 cells compared with the untreated $\mathrm{P} 815$ cells $(\mathrm{P}=0.0495, \mathrm{P}=0.0128, \mathrm{P}=0.0067$, respectively; Fig. 3A). Furthermore, similar results were demonstrated in activated P815 cells transfected with siRNA, with IL-4, IL-6 and $\beta$-hexosaminidase release significantly decreased in MMP9 siRNA-transfected P815 cells compared with control siRNA-transfected $\mathrm{P} 815$ cells $(\mathrm{P}=0.0490$, $\mathrm{P}=0.0099$ and $\mathrm{P}=0.0073$, respectively; Fig. 3B). These results 
suggested that MMP9 is involved in the activation of mast cells.

IL-4 inhibits MMP9 upregulation in activated mast cells. IL-4 has been previously demonstrated to inhibit MMP9 expression in rat synovial membranes incubated in vitro (23) and activated mast cells produce high levels of IL-4 (24). Therefore, it was hypothesized that IL-4 was involved in the regulation of MMP9 expression in activated mast cells. The protein expression of MMP9 was visibly inhibited in $10 \mathrm{ng} / \mathrm{ml}$ IL-4-treated activated P815 cells compared with untreated activated P815 cells (Fig. 4A). Furthermore, inhibiting IL-4 signaling using $10 \mu \mathrm{g} / \mathrm{ml}$ IL-4 neutralizing antibody resulted in visibly increased MMP9 protein levels in activated P815 cells compared with untreated activated P815 cells (Fig. 4B). These results indicated that IL-4 negatively regulates MMP9 expression in activated mast cells.

\section{Discussion}

$\mathrm{AR}$ is an important health problem due to its prevalence and its impact on the social life, school performance and work productivity of patients (25). Mast cells are the most important effector cells in AR (26). In general, mast cells are activated through cross-linkage of FceRI by antigen-specific IgE. They are key effectors in IgE-dependent hypersensitivity reactions (5). Ligation of FceRI, constitutively expressed on mast cells, promotes cell activation and immediate release and production of pro-inflammatory mediators, characterized by sneezing, itching, rhinorrhea and nasal obstruction, and AR may negatively impact AR patient's quality of life $(27,28)$. HMC-1 (27) and P815 (28) cell lines were often used to explore the mechanism of AR development, whereas there is no recognition about their involvement in mastocytoma. The present study, determined that MMP9 was implicated in PMA and ION-induced activation of mast cells. This finding provided a novel insight into the mechanisms underlying mast cell activation.

As a member of the MMP family, the primary function of MMP9 is to degrade the ECM, which facilitates the invasion and metastasis of tumors (29). MMP9 has also been demonstrated to regulate the release of inflammatory factors and cytokines. Binding of MMP9 to CD44 promotes the release of activated transforming growth factor- $\beta 1$ (30). MMP9 has also been previously reported to increase vascular endothelial growth factor release and promote angiogenesis (31). A variety of inflammatory factors and cytokines activate mast cells (32) and it is possible that MMP9 promotes PMA and ION-induced mast cell activation through the regulation of the inflammatory factors and cytokines involved in mast cell activation. However, further investigation is required to elucidate the precise mechanism.

High IL-4 levels are produced by activated mast cells. In the present study, it was demonstrated that IL-4 decreases MMP9 protein levels in activated mast cells, forming a negative feedback loop. In this manner, mast cells are able to limit self-activation. Inhibition of IL-4 expression has been proposed as an effective strategy for the treatment of airway inflammation (33). Therefore, attempts to negatively regulate IL-4 in mast cells must take this into consideration. Without further study, the comprehensive outcome of IL-4 inhibition to control airway inflammation remains difficult to determine.

In conclusion, MMP9 was upregulated during mast cell activation, and this upregulation was dependent upon normal function of the ERK and AKT signaling pathways. Increased MMP9 levels were demonstrated to further activate mast cells, whereas IL-4 inhibited the increase of MMP9 in activated mast cells. These findings revealed a novel mechanism underlying mast cell activation, which enhances current understanding and may provide novel targets for the treatment of AR.

\section{Acknowledgements}

The present study was supported by the Natural Science Foundation of Zhejiang Province (grant no. LY12H13003) and the Medical Scientific Research Foundation of Zhejiang Province (nos. 2010KYA104 and 2012KYA098).

\section{References}

1. Ridolo E, Montagni M, Melli V, Bonzano L, Incorvaia C and Canonica GW: A role for the intranasal formulation of azelastine hydrochloride/fluticasone propionate in the treatment of allergic rhinitis. Ther Deliv 6: 653-659, 2015.

2. Brozek JL, Bousquet J, Baena-Cagnani CE, Bonini S, Canonica GW, Casale TB, van Wijk RG, Ohta K, Zuberbier T, Schünemann HJ, et al: Allergic Rhinitis and its Impact on Asthma (ARIA) guidelines: 2010 Revision. J Allergy Clin Immunol 126: 466-476, 2010.

3. Hadley JA, Derebery MJ and Marple BF: Comorbidities and allergic rhinitis: Not just a runny nose. J Fam Pract 61 (2 Suppl): S11-S15, 2012.

4. Williams CM and Galli SJ: The diverse potential effector and immunoregulatory roles of mast cells in allergic disease. J Allergy Clin Immunol 105: 847-859, 2000.

5. Robbie-Ryan $\mathrm{M}$ and Brown $\mathrm{M}$ : The role of mast cells in allergy and autoimmunity. Curr Opin Immunol 14: 728-733, 2002.

6. Woolhiser MR, Okayama Y, Gilfillan AM and Metcalfe DD: IgG-dependent activation of human mast cells following up-regulation of FcgammaRI by IFN-gamma. Eur J Immunol 31: 3298-3307, 2001.

7. Wang JX, Kaieda S, Ameri S, Fishgal N, Dwyer D, Dellinger A Kepley CL, Gurish MF and Nigrovic PA: IL-33/ST2 axis promotes mast cell survival via BCLXL. Proc Natl Acad Sci USA 111: 10281-10286, 2014.

8. Juremalm M and Nilsson G: Chemokine receptor expression by mast cells. Chem Immunol Allergy 87: 130-144, 2005.

9. Okayama Y, Saito H and Ra C: Targeting human mast cells expressing g-protein-coupled receptors in allergic diseases. Allergol Int 57: 197-203, 2008.

10. Oskeritzian CA, Price MM, Hait NC, Kapitonov D, Falanga YT, Morales JK, Ryan JJ, Milstien S and Spiegel S: Essential roles of sphingosine-1-phosphate receptor 2 in human mast cell activation, anaphylaxis, and pulmonary edema. J Exp Med 207: 465-474, 2010.

11. Bratcher PE, Weathington NM, Nick HJ, Jackson PL, Snelgrove RJ and Gaggar A: MMP-9 cleaves SP-D and abrogates its innate immune functions in vitro. PLoS One 7: e41881, 2012.

12. Vandenbroucke RE, Dejonckheere E and Libert C: A therapeutic role for matrix metalloproteinase inhibitors in lung diseases? Eur Respir J 38: 1200-1214, 2011.

13. Gauchotte G, Marie B, Gallet P, Nguyen DT, Grandhaye M, Jankowski R and Vignaud JM: Respiratory epithelial adenomatoid hamartoma: A poorly recognized entity with mast cell recruitment and frequently associated with nasal polyposis. Am J Surg pathol 37: 1678-1685, 2013.

14. Purwar R, Kraus M, Werfel T and Wittmann M: Modulation of keratinocyte-derived MMP-9 by IL-13: A possible role for the pathogenesis of epidermal inflammation. J Invest Dermatol 128: 59-66, 2008.

15. Abel $\mathrm{M}$ and Vliagoftis $\mathrm{H}$ : Mast cell-fibroblast interactions induce matrix metalloproteinase-9 release from fibroblasts: Role for IgE-mediated mast cell activation. J Immunol 180: 3543-3550, 2008. 
16. Brower GL, Chancey AL, Thanigaraj S, Matsubara BB and Janicki JS: Cause and effect relationship between myocardial mast cell number and matrix metalloproteinase activity. Am J Physiol Heart Circ Physiol 283: H518-H525, 2002.

17. Tchougounova E, Lundequist A, Fajardo I, Winberg JO, Abrink M and Pejler G: A key role for mast cell chymase in the activation of pro-matrix metalloprotease-9 and pro-matrix metalloprotease-2. J Biol Chem 280: 9291-9296, 2005.

18. Abel $\mathrm{M}$ and Vliagoftis $\mathrm{H}$ : Mast cell-fibroblast interactions induce matrix metalloproteinase-9 release from fibroblasts: Role for IgE-mediated mast cell activation. J Immunol 180: 3543-3550, 2008.

19. Kanbe N, Tanaka A, Kanbe M, Itakura A, Kurosawa M and Matsuda H: Human mast cells produce matrix metalloproteinase 9. Eur J Immunol 29: 2645-2649, 1999.

20. Livak KJ and Schmittgen TD: Analysis of relative gene expression data using real-time quantitative PCR and the 2(-Delta Delta C(T)) method. Methods 25: 402-408, 2001.

21. Silwal P, Shin K, Choi S, Kang SW, Park JB, Lee HJ, Koo SJ, Chung KH, Namgung U, Lim K, et al: Adenine suppresses IgE-mediated mast cell activation. Mol Immunol 65: 242-249, 2015.

22. Dahiya S, Givvimani S, Bhatnagar S, Qipshidze N, Tyagi SC and Kumar A: Osteopontin-stimulated expression of matrix metalloproteinase- 9 causes cardiomyopathy in the mdx model of Duchenne muscular dystrophy. J Immunol 187: 2723-2731, 2011.

23. Hyc A, Osiecka-Iwan A, Niderla-Bielinska J and Moskalewski S: Influence of LPS, TNF, TGF-ss1 and IL-4 on the expression of MMPs, TIMPs, and selected cytokines in rat synovial membranes incubated in vitro. Int J Mol Med 27: 127-137, 2011.

24. McLeod JJ, Baker B and Ryan JJ: Mast cell production and response to IL-4 and IL-13. Cytokine 75: 57-61, 2015.
25. Bousquet J, Khaltaev N, Cruz AA, Denburg J, Fokkens WJ, Togias A, Zuberbier T, Baena-Cagnani CE, Canonica GW, van Weel C, et al: Allergic Rhinitis and its Impact on Asthma (ARIA) 2008 update (in collaboration with the World Health Organization, GA(2)LEN and AllerGen). Allergy 63 (Suppl 86): S86-S88, 2008.

26. Bernstein DI, Schwartz G and Bernstein JA: Allergic Rhinitis: Mechanisms and Treatment. Immunol Allergy Clin North Am 36: 261-278, 2016.

27. Kim HY, Nam SY, Hwang SY, Kim HM and Jeong HJ: Atractylone, an active constituent of KMP6, attenuates allergic inflammation on allergic rhinitis in vitro and in vivo models. Mol Immunol 78: 121-132, 2016.

28. Lin H, Zheng C, Li J, Yang C and Hu L: Lentiviral shRNA against $\mathrm{KCa} 3.1$ inhibits allergic response in allergic rhinitis and suppresses mast cell activity via PI3K/AKT signaling pathway. Sci Rep 5: 13127, 2015.

29. Wang F, He W, Fanghui P, Wang L and Fan Q: NF-kappaBP65 promotes invasion and metastasis of oesophageal squamous cell cancer by regulating matrix metalloproteinase- 9 and epithelial-to-mesenchymal transition. Cell Biol Int 37: 780-788, 2013.

30. Yu Q and Stamenkovic I: Cell surface-localized matrix metalloproteinase-9 proteolytically activates TGF-beta and promotes tumor invasion and angiogenesis. Genes Dev 14: 163-176, 2000

31. Gupta A, Zhou CQ and Chellaiah MA: Osteopontin and MMP9: Associations with VEGF expression/secretion and angiogenesis in PC3 prostate cancer cells. Cancers (Basel) 5: 617-638, 2013.

32. Yu Y, Blokhuis BR, Garssen J and Redegeld FA: Non-IgE mediated mast cell activation. Eur J Pharmacol 778: 33-43, 2016.

33. Lee CC, Huang HY and Chiang BL: Lentiviral-mediated interleukin-4 and interleukin-13 RNA interference decrease airway inflammation and hyperresponsiveness. Hum Gene Ther 22: 577-586, 2011. 